\title{
Velkommen til vol 14/1 - den første utgaven publisert under tittelen Acta Didactica Norden
}

Det er med stor glede jeg kan presentere vol. 14/1 - det aller første nummeret utgitt under tittelen Acta Didactica Norden. Som tidligere meddelt ble tidsskriftets navn oppdatert ved inngangen til 2020, fra Acta Didactica Norge til Acta Didactica Norden. Det nye navnet gjenspeiler mer presist tidsskriftets forfatter- og leserkrets, så vel som sammensetningen av redaksjon og redaksjonsråd. Redaksjonen gleder seg over en stadig økende tilstrømming av manuskripter skrevet av forfattere i ulike nordiske land, noe som etter hvert begynner å vises i publiserte utgaver. Inneværende utgave inneholder for eksempel fire bidrag fra Sverige, hvorav to er skrevet på svensk og to på engelsk.

Vol. 14/1 er et omfangsrikt nummer, med hele 22 artikler. Fem av disse handler om skriveopplæring, i ulike former og på ulike utdanningsnivåer. Svanes \& Øgreid tar for seg læreres stillasbygging i skriveopplæring på barnetrinnet. Skar, Jølle \& Aasen skriver også om barnetrinnet, idet de fokuserer på vurdering av skriveferdigheter for 1.-3- trinn. Dversnes studerer bruk av eksempeltekster i skriveopplæringen på ungdoms- og videregående skole, mens Jahnsen \& Bakken konsentrerer seg om elever i videregående skole og deres kompetanse når det gjelder tekstrevisjon. Hellne-Halvorsen \& Spetalen undersøker hvordan det arbeides med skriving i lærerutdanningen, nærmere bestemt på yrkesfaglige lærerutdanningsprogrammer.

Utover artiklene om skriving, er språkfaglige temaer generelt godt representert i denne utgaven av ADNO. Morsmålsfaget er representert med to artikler fra norskfaget. Haugen \& Spilling undersøker hvordan lærebøker for 3. og 4. trinn forklarer og presenterer ordklasser, mens Rogne tar for seg norskfaget i grunnskolelærerutdanningen og diskuterer nyere utviklingstrekk ved faget. Tre artikler omhandler ulike aspekter ved flerspråklighet. Aho skriver om nyankomne videregående-elever i Sverige og deres opplevelse av det språklige introduksjonsprogrammet de følger. Kjelaas, Eide, Vidarsdottir \& Hauge skriver om nyankomne videregående-elever i Norge, og deres artikkel kaster et kritisk blikk på praksisen med kartlegging av disse elevenes språkkompetanse. Fløgstad setter søkelyset på romani som nasjonalt minoritetsspråk og diskuterer hvordan lærere kan møte ulike former for flerspråklighet i klasserommet.

Praktisk-estetiske fag er også godt representert i denne utgaven av ADNO, først og fremst med kroppsøvingsfaget. Tre artikler handler om dette faget: Borgen \& Engelsrud analyserer den nye norske læreplanen i kroppsøving, innført med læreplanreformen Fagfornyelsen i 2020. Ulstad, Valstadsve \& Skjesol skriver om 
betydningen av å skape et mestringsorientert fremfor et prestasjonsorientert klima for elevene i kroppsøvingsfaget. Mjåtveit \& Giske fokuserer på lærerutdanningen i dette faget, og undersøker hvilken plass formativ vurdering har i praksisdelen av utdanningen. I en artikkel skrevet av Borgen, Hallås, Seland, Aadland \& Vindenes, løftes blikket til de praktisk-estetiske fagene som gruppe, og artikkelen omhandler mat \& helse, musikk, og kunst- og håndverksfaget så vel som kroppsøving. Forfatterne gir en historisk analyse av styringsdokumenter som belyser hvordan disse fagene er blitt konseptualisert opp igjennom tiden.

Samfunnsfagene er representert med to artikler fra ungdomsskolenivå. Elmersjö \& Thorp diskuterer hvordan læreres egne livserfaringer under den kalde krigen påvirker deres historieundervisning om dette temaet. Lønnum \& Mørk undersøker og diskuterer bruken av ETOS-modellen for kildearbeid og kildekritikk i samfunnsfag.

Naturfagene er likeledes representert med to artikler: Häggström analyserer et utendørs undervisningsopplegg i naturfag, og diskuterer hvordan barneskoleelever opplever det å få utforske et skogsmiljø på egenhånd. Kvello, Barstad, Rønning, Moen \& Østerlie sammenligner omvendt og tradisjonell undervisning i naturfag, og diskuterer hvordan disse undervisningsformene virker inn på elevers motivasjon og læringsutbytte.

Digitalisering, uavhengig av fag, er et stadig aktuelt tema, og i denne utgaven av ADNO finner vi to artikler som berører dette feltet spesielt. Grüters skriver om hvordan finske barneskolelærere implementerte en nasjonalt vedtatt IKT-strategi fra 2014 i sitt klasserom, mens Hjukse, Aagard, Bueie, Moser \& Vika konsentrerer seg om lærerutdanningsnivået, og diskuterer hvordan det arbeides med profesjonsfaglig digital kompetanse i ulike fag i grunnskolelærerutdanningen.

Til slutt har vi to artikler som tar for seg ulike storskala internasjonale tester. Rasmussen, Kjærnsli, Jensen \& Ludvigsen skriver om norske elevers resultater på problemløsingsoppgaver i PISA-testene. Nilsen \& Bergem er opptatt av hvordan lærerkompetanse kan bidra til å utjevne påvirkning fra elevers hjemmebakgrunn på faglige resultater. De bruker data fra TIMSS-undersøkelser i Norge, Sverige og Finland for å studere sammenhengen mellom lærerkompetanse og skolers sosioøkonomiske status.

Med dette vil jeg på vegne av redaksjonen ønske god lesning og en fortsatt god sommer til alle ADNOs lesere og bidragsytere!

Sommer 2020

Eva Thue Vold

Ansvarlig redaktør 